\section{EFFECT OF IMMOBILIZATION PARAMETERS ON THE IMMOBILIZATION OF CYCLODEXTRIN GLUCANOTRANFERASE ON HOLLOW FIBER MEMBRANE}

\author{
N. Jamil, R. C. Man*, S. Suhaimi, S. M. Shaarani, Z. I. M. Arshad, S. K.
} A. Mudalip, S. Z. Sulaiman

Faculty of Chemical and Natural Resources Engineering, Universiti Malaysia Pahang, Lebuhraya Tun Razak, 26300 Kuantan, Pahang, Malaysia
Article history

Received

30 May 2019

Received in revised form

13 October 2019

Accepted

4 November 2019

Published online

25 December 2019

*Corresponding author rohaida@ump.edu.my

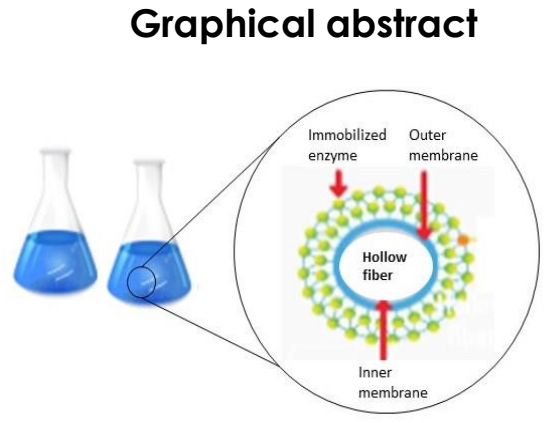

Immobilization of CTase on hollow fiber membrane

\begin{abstract}
Cyclodextrin (CD) is a non-reducing maltooligosaccharides which able to form inclusion complexes with many hydrophobic molecules, changing their physical and chemical properties. With these properties, CD has been discovered to have numerous applications in food industries, pharmaceutical, agricultural and environmental engineering. $C D$ is produced by the enzymatic reaction between cyclodextrin glucanotransferase (CGTase) and starch. Various enzyme immobilization techniques such as adsorption, entrapment, encapsulation and cross-linking have been applied to improve the production of CD. Some of the immobilization parameters such as contact time, agitation rate and $\mathrm{pH}$ of the immobilization solution play a vital role in enzyme immobilization process, in order to achieve high production of CD. In the present study, the CGTase from Bacillus licheniformis was immobilized on polyvinylidene difluoride (PVDF) hollow fiber membrane via adsorption technique. The efficiency of enzyme immobilization appears to be affected by various factors (immobilization parameters) such as contact time, agitation rate and $\mathrm{pH}$. Therefore, the effect of contact time (6-72 h), agitation rate (50-250 rpm) and $\mathrm{pH}(3-10)$ on the immobilization of CGTase on PVDF hollow fiber membrane were investigated in this study. The immobilized CGTase exhibited the highest immobilization yield of $69.37 \%$ under the conditions of $24 \mathrm{~h}$ contact time, $100 \mathrm{rpm}$ and $\mathrm{pH}$ 7.0. Therefore, the influence of the immobilization parameters during the enzyme immobilization process is vital in order to achieve the high production of CD. Hence, high immobilization yield contributed to the high production of $C D$ which in turn may be beneficial for the industrial purposes.
\end{abstract}

Keywords: Adsorption, CGTase, hollow fiber membrane, immobilization parameter, cyclodextrin

\begin{abstract}
Abstrak
Siklodekstrin (CD) adalah sebation maltooligosakarida bukan penurun yang mampu membentuk kompleks inklusif dengan pelbagai molekul hidrofobik yang membolehkan ia mengubah sifat fizikal dan kimia molekul tersebut. Dengan ciriciri ini, CD telah ditemui mempunyai banyak aplikasi dalam industri makanan, farmaseutikal, pertanian dan kejuruteraan alam sekitar. CD dihasilkan oleh reaksi enzimatik antara siklodekstrin glucanotransferase (CGTase) dan kanji. Pelbagai teknik immobilisasi enzim seperti penjerapan, perangkap, pengkapsulan dan pemaut silang telah digunakan untuk meningkatkan pengeluaran $\mathrm{CD}$. Beberapa parameter imobilisasi seperti masa hubungan, kadar agitasi dan $\mathrm{pH}$ larutan imobilisasi memainkan peranan penting dalam proses imobilisasi enzim, untuk
\end{abstract}


mencapai pengeluaran CD yang tinggi. Dalam kajian ini, CGTase dari Bacillus licheniformis telah dimobilisasikan pada membran gentian berongga poliviniliden fluorida (PVDF) melalui teknik penjerapan. Kecekapan imobilisasi enzim dipengaruhi oleh pelbagai faktor (parameter imobilisasi) seperti masa hubungan, kadar agitasi dan $\mathrm{pH}$. Oleh itu, kesan masa hubungan (6-72 jam), kadar agitasi (50-250 rpm) dan pH (3-10) terhadap immobilisasi CGTase pada membran gentian berongga PVDF telah dikaji dalam kajian ini. CGTase yang diimobilisasi mempamerkan hasil imobilisasi tertinggi sebanyak $69.37 \%$ pada 24 jam masa hubungan, $100 \mathrm{rpm}$ dan $\mathrm{pH}$ 7.0. Oleh itu, pengaruh parameter imobilisasi semasa proses imobilisasi enzim adalah penting untuk mencapai pengeluaran CD yang tinggi. Oleh itu, hasil imobilisasi yang tinggi menyumbang kepada penghasilan CD yang tinggi yang seterusnya memberi manfaat untuk tujuan perindustrian.

Kata kunci: Penjerapan, CGTase, membran gentian berongga, parameter imobilisasi, cyclodextrin

(c) 2020 Penerbit UTM Press. All rights reserved

\subsection{INTRODUCTION}

Cyclodextrin glucanotransferase (CGTase, EC 2.4.1.19) is one of a-amylase family that catalyzed four related reactions including cyclization, hydrolysis, disproportionation and coupling of starch [1]. The most important application of CGTase is in the production of cyclodextrin (CD) by cyclization process [2]. The steric arrangement of glucose monomer in the CD results in the shape of a hollow truncated cone with a hydrophilic surface outside and hydrophobic cavity inside [3]. Because of these features, CDs are able to form inclusion complexes with various guest molecules thus making CDs an attractive inclusion agent for numerous applications in diverse field such as food, pharmaceutical and cosmetic [4].

Since $C D$ is growing popular due to their numerous applications in industries, the study and production using CGTase have been a great interest to researchers. However, in commercialization of CGTase for the industrial purposes, the processes are highly challenging due to the instability of the enzyme, sensitivity to the process conditions and high cost of isolation and purification of the enzyme $[5,6]$. The instability of enzyme during the reaction process resulted in the low production of CD. Therefore, enzyme immobilization technique is applied to improve the enzyme stability in order to achieve high production of $C D$.

Enzyme immobilization is process that involve the attachment of the enzyme to or within the support phase by several methods [7]. Enzyme can be immobilized by a variety of techniques which may be broadly classified as physical and chemical techniques. Physical technique involves physical adsorption, entrapment and microencapsulation. Chemical technique occurs when covalent bonds are formed between the support and enzyme [8]. Entrapment of enzyme onto polymer protects the enzyme by preventing the direct contact between the enzyme and the environment. However, its drawbacks of mass transfer limitation and enzyme leakage were found to be in most studies [9].
Immobilization of enzyme via cross-linking has the major disadvantages of expensive and reduce enzyme catalytic activity due to the toxicity of the reagents [10]. Therefore, adsorption method has been chosen in the present study as it remains as the most attractive method due to its simplicity, inexpensive and does not involve pre-treatment with other reagents.

There are numerous studies of enzyme immobilization by using several types of supports such as alginate [11], chitosan [12], chitin [13], silica [3] and hollow fiber membrane [14] that have been successfully observed. Compared to other supports, hollow fiber membrane offers several distinct advantages such as larger surface area to volume ratio, high mechanical strength, operational durability, lack of toxicity, good thermal property and excellent chemical resistance [15-17]. In addition, the hollow fiber membrane is economically attractive since this membrane is readily available and inexpensive [18]. Moreover, membrane-type system is suitable to be employed for scale-up operation due to its simple and easy operation as well as maintenance [16].

In this study, polyvinylidene fluoride (PVDF) hollow fiber membrane was used for immobilization of CGTase. PVDF hollow fiber membrane that act as hydrophobic membrane and possess both positive (hydrogen ion) and negative charged ion (fluoride ion) give major advantages compared to other support [19]. With these properties, immobilization of enzyme on the support surface can be occurred by electrostatic and hydrophobic interaction whereas, other membrane only possesses electrostatic interaction [20]. Therefore, on the adsorption of CGTase on PVDF hollow fiber membrane, enzyme pre-treatment in immobilization process does not required and toxicity of the reagent can be prevented. Results presented here suggest that immobilization of CGTase on the PVDF hollow fiber membrane is a promising technique to improve production of $C D$. 
The immobilization conditions such as enzyme concentration, temperature, reaction time, $\mathrm{pH}$ and agitation rate should be properly studied to enhance the immobilization efficiency and stability of the immobilized enzyme. The effect of time on the enzyme immobilization system has shown to be important for enhancing the immobilization efficiency. A study conducted by Martin et al. [21] reported that, the catalytic efficiency of the immobilized CGTase on Eupergit $C$ was increased with the increase of incubation time from $24 \mathrm{~h}$ to 72 h. Then, the CGTase catalytic efficiency remain constant as the incubation time increased from 72 to $120 \mathrm{~h}$.

The agitation rate is one of the important factors in providing an adequate time for the attachment of the enzyme to the matrix. Moreover, the external mass transfer and internal diffusion limitation in enzyme immobilization can be minimize by carrying the process at an optimum agitation rate [22]. A study conducted by Rahim et al. [23] showed that the activity of immobilized a-amylase on calcium alginate-clay beads was increased with the increase of agitation rate from 40 to $120 \mathrm{rpm}$. However, further increase of agitation rate from 120 to $200 \mathrm{rpm}$ results in decrease of the enzyme activity due to the shear stress that could cause the inactivation of enzyme [24].

The $\mathrm{pH}$ of the buffer is another factor that might influence the attachment of enzyme to the support. The effect of $\mathrm{pH}$ on the immobilization of CGTase on Eupergit $C$ was investigated by Martín et al. [21]. The optimum binding of CGTase on Eupergit $C$ was achieved at $\mathrm{pH} 7$ with highest catalytic efficiency (7.0\%) and $71 \%$ of immobilization yield (Martín et al., 2003). Decrease in the CGTase catalytic efficiency was observed at lower $\mathrm{pH}(\mathrm{pH} 4)$ and higher $\mathrm{pH}(\mathrm{pH}$ 8). The results showed that the activity of the immobilized enzyme was significantly affected by the $\mathrm{pH}$. Therefore, the aim of this study is to determine the best immobilization conditions for immobilization of CGTase on PVDF hollow fiber membrane. The effect of contact time, agitation rate and $\mathrm{pH}$ on the immobilization of CGTase were investigated.

\subsection{MATERIALS AND METHODOLOGY}

\subsection{Materials and Chemicals}

Commercial CGTase from Bacillus licheniformis (Toruzyme 3.0L) was purchased from Novozymes A/S (Bagsvaerd, Denmark). The polyvinylidene fluoride (PVDF) and hollow fiber membrane was procured from Separation and Membrane Cluster, Faculty of Chemical Engineering and Natural Resources, Universiti Malaysia Pahang (UMP, Malaysia). The standard of a-cyclodextrin (98\%) was purchased from Sigma-Aldrich (St. Louis, USA). Potato soluble starch was purchased from Friendemann Schmidt (Parkwood, Australia).

\subsection{Immobilization of CGTase}

The PVDF membranes were cut into $3 \mathrm{~cm}$ and transferred into $9.0 \mathrm{ml}$ of $0.05 \mathrm{M}$ sodium phosphate buffer (pH 6.0) containing $1.0 \mathrm{ml}$ of enzyme. The immobilization process was carried out at $25{ }^{\circ} \mathrm{C}$ temperature with gentle orbital shaking of $150 \mathrm{rpm}$ for $24 \mathrm{~h}$ incubation. After incubation, the immobilized enzyme was collected and rinsed thoroughly with 0.1 $M$ phosphate buffer (pH 6.0) and immediately stored at $4{ }^{\circ} \mathrm{C}$. CGTase activity in the remaining buffer was further analyzed under standard enzyme assay. The immobilization yield was calculated as in (1).

$$
\text { Immobilization yield }(\%)=(A-B) / A \times 100
$$

Where $A$ is the initial amount of CGTase before immobilization and $B$ is the amount of CGTase in remaining buffer after immobilization.

\subsection{Effect of Immobilization Parameters}

\subsubsection{Effect of Agitation Rate}

The effect of agitation rate on the immobilization of CGTase was studied by incubating the solution for 24 h at various speeds of 50, 100, 150, 200, and $250 \mathrm{rpm}$ [20].

\subsubsection{Effect of Contact Time}

The effect of time on the immobilization of CGTase on the hollow fiber membrane was determined by incubating the solution at $6,12,24,48$, and $72 \mathrm{~h}$ based on the study conducted by Ibrahim et al. [3].

\subsubsection{Effect of $\mathrm{pH}$}

The effect of $\mathrm{pH}$ on the enzyme immobilization on hollow fiber membrane was examined from $\mathrm{pH}$ 3-10 by using various buffers including phosphate-citrate buffer (pH 3-5), sodium phosphate buffer $(\mathrm{pH}$ 6-8) and glycine-NaOH buffer (pH 9-10) as described by Li et al. [25].

\subsection{CGTase Assay}

CGTase activity was performed by methyl orange method according to the previous study [26]. Briefly, $0.1 \mathrm{~mL}$ of enzyme was added into $0.9 \mathrm{~mL}$ of $3 \%(\mathrm{w} / \mathrm{v})$ soluble starch in $0.05 \mathrm{M}$ phosphate buffer $(\mathrm{pH} 6.0)$, before incubation at $40{ }^{\circ} \mathrm{C}$ for $10 \mathrm{~min}$. The reaction was terminated by adding $1.0 \mathrm{~mL}$ of $1.0 \mathrm{M} \mathrm{HCl}$ and $0.1 \mathrm{~mL}$ of $0.01 \mathrm{M}$ methyl orange. After $20 \mathrm{~min}$ of incubation at $16^{\circ} \mathrm{C}$, the amount of a-CD was spectrophotometrically at $507 \mathrm{~nm}$. The activity of aCGTase shows the amount of enzyme that is able to produce $1 \mathrm{~mol}$ of a-CD per min [27]. 


\subsection{RESULTS AND DISCUSSION}

The efficiency of the enzyme immobilization appears to be affected by various factors such as temperature, enzyme concentration, $\mathrm{pH}$, agitation rate and contact time. These factors can affect the process of the immobilization, the attachment of enzyme on the support and also the production of desired product. Therefore, the influences of the immobilization parameters in the enzyme immobilization process were investigated in order to achieve the desired immobilized enzyme.

\subsection{Effect of Contact Time}

Contact time is one of the critical variables that would affect the immobilization of CGTase on the hollow fiber membrane. In this study, the immobilization of CGTase was performed at various contact time ranging from 6 to $72 \mathrm{~h}$. The influence of the contact time on the immobilization of CGTase on the hollow fiber membrane is presented in Figure 1. From the result, it showed that at 6 and $12 \mathrm{~h}$ of contact time, there were only $4.94 \%$ and $30.52 \%$ of enzyme that were successfully immobilized on the hollow fiber membrane, respectively. When the time reached $24 \mathrm{~h}$ of contact time, the immobilization yield was significantly increased to $60.95 \%$. The increase of contact time had improved the amount of enzyme interacted to the surface of the support and enhancing the immobilization process. A similar result was observed in the study conducted by Li et al. [25], whereby the immobilization yield of pectinase on the activated agar-gel support was increased with the increased of time from $4 \mathrm{~h}$ to $24 \mathrm{~h}$ of contact time.

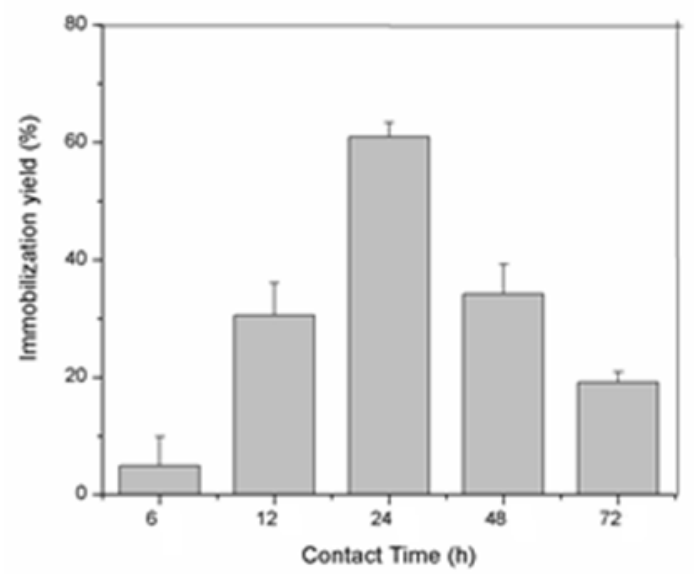

Figure 1 Effect of contact time on the CGTase immobilization on PVDF membrane

However, another study of pectinase immobilized onto amphiphilic block copolymers showed that the optimum immobilization yield was achieved at only 1 $\mathrm{h}$ of contact time [28]. This shows that although the immobilization process may be very rapid in some research, multipoint interaction between the enzyme and the support surface is a time dependent process [29]. Immobilization process required correct alignment of groups located on the enzyme and the support surface, otherwise the adsorption will not occur [30]. The results may varies depending on the type of enzyme and support been used.

Therefore, the immobilization of CGTase on the hollow fiber membrane in the present study required $24 \mathrm{~h}$ of contact time to achieve a maximum immobilization yield. As shown in Figure 1, as the contact time increased to $72 \mathrm{~h}$, the immobilization yield was significantly decreased to $19.17 \%$. This is due to the detachment of enzyme from the support surface. According to Pang et al. [31], during the physical adsorption, detachment of enzyme from the support can be occurred when it was immersed in the immobilization solution for a long period of time.

\subsection{Effect of Agitation Rate}

The immobilization of CGTase was carried out at a constant temperature of $25{ }^{\circ} \mathrm{C}$ with different agitation rate of $50,100,150,200$ and $250 \mathrm{rpm}$ to determine the optimal agitation rate for the immobilization process. Results in Figure 2 illustrated that the low immobilization yield of $45.11 \%$ was recorded at $50 \mathrm{rpm}$ compared to $69.74 \%$ of immobilization yield at $100 \mathrm{rpm}$. Low immobilization yield at $50 \mathrm{rpm}$ of agitation rate can be correlated with the non-uniform distribution of the enzyme in the immobilization mixture during the adsorption process [32].

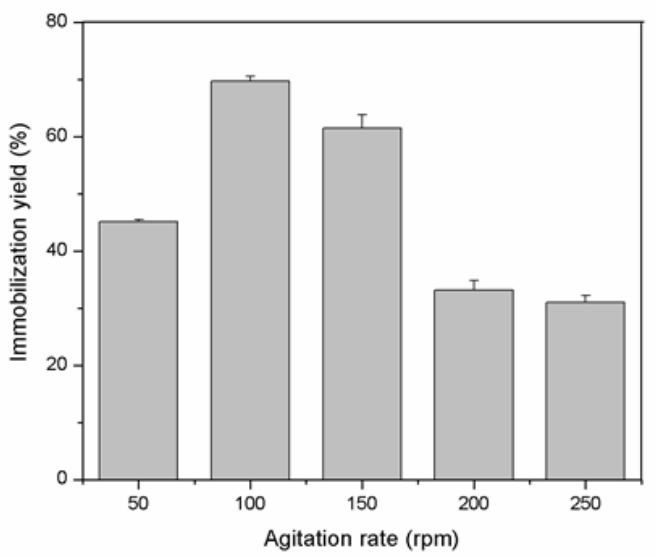

Figure 2 Effect of agitation rate on the immobilization yield of CGTase on PVDF membrane

As the agitation rate increased from 50 to 100 rpm, increased of immobilization yield by $25 \%$ was observed. This phenomenon was due to the higher shear values at higher agitation rate. According to Man et al. [20], at high shear values, the enzyme was pulled closer to the support and attributed to the increased of electrostatic and hydrophobic interaction. Moreover, when the mixture was agitated reasonably, more surface area of the 
support was exposed to the enzyme and allowing more enzyme to interact with the hollow fiber membrane.

However, too vigorous agitation rate had significantly decreased the CGTase immobilization yield. More than $38 \%$ reduction in CGTase immobilization yield was recorded when the agitation rate was increased to $250 \mathrm{rpm}(31.01 \%)$ and followed by $33.18 \%$ at $200 \mathrm{rpm}$. The reduction of immobilization yield was correlated with the detachment of the immobilized CGTase from the support surface due to the shear forces created by the vigorous shaking. As shown in Table 1, high agitation rate resulted in the increase of the detachment of the enzyme from hollow fiber membrane into the mixture.

Table 1 Detachment of the enzyme at various agitation rates

\begin{tabular}{cc}
\hline $\begin{array}{c}\text { Agitation rate } \\
\text { (rpm) }\end{array}$ & Detachment of CGTase (U/ml) \\
\hline 50 & 48.30 \\
100 & 33.60 \\
150 & 55.10 \\
200 & 80.40 \\
250 & 95.44 \\
\hline
\end{tabular}

The highest detachment of enzyme recorded was $95.4 \mathrm{U} / \mathrm{ml}$ at $250 \mathrm{rpm}$ and $80.4 \mathrm{U} / \mathrm{ml}$ at $200 \mathrm{rpm}$, which indicated that a vigorous agitation rate would increase the detachment of the enzyme from the support. This phenomenon had also been observed on the study of the immobilized xylanase on activated alginate beads by covalent attachment whereby the reduction of the immobilization yield was observed when increased of agitation rate from $50 \mathrm{rpm}$ (51.4\%) to $250 \mathrm{rpm}$ (49.6\%) [33]. This study demonstrated that the enzyme tends to detach easily from the support surface due to the higher shear stress caused by the increase of the enzyme and support collision at higher agitation rate.

\subsection{Effect of pH}

Immobilization of CGTase on hollow fiber membrane at different $\mathrm{pH}$ values was investigated to determine the optimum $\mathrm{pH}$ at which the enzyme-support interaction was favored. The optimum attachment of the CGTase on the hollow fiber membrane was achieved at pH 7.0 with $69.37 \%$ of the immobilization yield followed by pH 6.0 with $58.2 \%$ of immobilization yield as shown in Figure 3 . These results could be explained by the charging phenomenon at the surface of the enzyme which is $\mathrm{pH}$-dependent. The highest immobilization yield was observed at $\mathrm{pH}$ 7.0, which is close to the isoelectric point of CGTase ( $\mathrm{pl}$ 6.5) [34]. This finding was supported by Ajitha \& Sugunan [35], whereby the maximum adsorption of a-amylase on mesoporous sieve was occurred at $\mathrm{pH}$ 6.0 which is near to the isoelectric point of a-amylase (pl 5.5).
From Figure 3, it is clearly shown that the immobilization efficiency was significantly affected by the changes of $\mathrm{pH}$. The immobilization of CGTase on the hollow fiber membrane showed a decreased in immobilization yield when incubated in more acidic (pH 3.0 - 5.0) and more alkaline (pH 8.0 - 10.0). This reduction of enzyme immobilization yield could be explained by the electrostatic repulsion effects between the same charged groups on the enzyme and the support surface. Generally, hydrophobic interaction should not be affected by the $\mathrm{pH}$ of the immobilization system [36]. However, adsorption processes which also govern by the electrostatic interaction are very $\mathrm{pH}$-dependent. The slight changes of the $\mathrm{pH}$ of the immobilization system would affect the total net charge of the enzyme and the support that may resulted in the repulsion between the enzyme and the support.

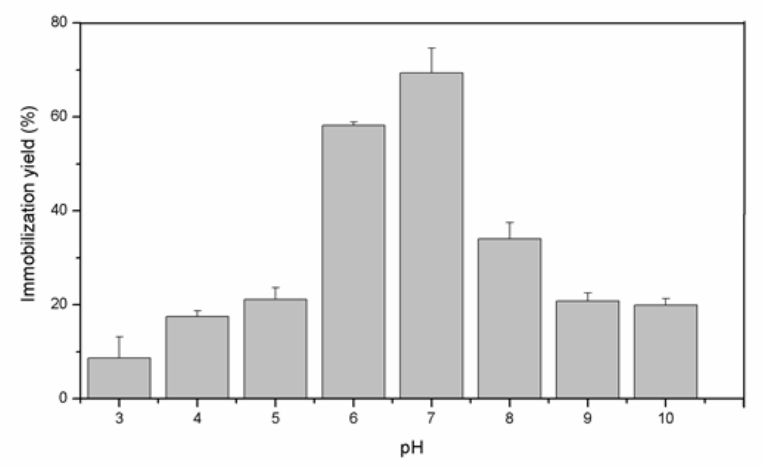

Figure 3 Effect of $\mathrm{pH}$ on the immobilization yield of CGTase on PVDF membrane

According to Sun et al. [37], the enzyme environmental $\mathrm{pH}$ ( $\mathrm{pH}$ of immobilization mixture) would influence the attachment of the enzyme on the support by altering their charges. Enzymes are amphoteric molecules that contain both basic [OH-] and acid $\left[\mathrm{H}^{+}\right]$groups that are located on their surface and would determine the total net charge of the enzyme. Therefore, as the total net charge of the enzyme was disrupted by the extreme $\mathrm{pH}$ value in the immobilization solution, the electrostatic repulsion between enzyme and the support were increased and the immobilization yield would decrease. A similar result was recorded by Wang et al. (38) on the immobilization of glucoamylase on magnetic chelator particles by adsorption technique. In the study, decreased in the enzyme immobilization efficiency was also recorded in the more acidic $(\mathrm{pH}$ 6.0-7.0) and more alkaline (pH 3.0-4.0) conditions, which correlated by the electrostatic repulsion between the support and the enzyme. The maximum immobilization efficiency of glucoamylase was recorded at $\mathrm{pH} 5.5$ which was near to the enzyme isoelectric point (pl 4.5). 


\subsection{CONCLUSION}

In conclusion, adsorption which majorly involved physical attachment of enzyme on the support is one of the simple immobilization techniques. The effect of contact time on the immobilization yield can be observed by two phases whereby at first phase, the immobilization yield was increased from $4.94 \%$ to $60.95 \%$ with the increased of contact time (6-24 h) and in the second phase, the immobilization yield was decreased from $32.9 \%$ to $19.17 \%$ as the contact time was further increase (48-72 h). This showed that at the second phase, desorption of the enzyme might be occurred. Apart from that, moderate agitation rate of $100 \mathrm{rpm}$ is important to minimize the high shear force at high agitation rate, detachment of the enzyme from the support and also damage of the support. Moreover, physical adsorption usually involved electrostatic interaction that varying due to the immobilization conditions such as $\mathrm{pH}$ of the immobilization solution. Therefore, near to the neutral $\mathrm{pH}$ (pH 7.0) promoted a better adsorption of CGTase on the hollow fiber membrane due to the effective electrostatic interaction. As the result the interaction between the CGTase and the hollow fiber membrane was enhanced and more enzyme molecules were attracted and absorbed on the support. Thus, this study showed that the efficiency of the enzyme immobilization process is highly related with the immobilization conditions. In addition, immobilization conditions for the enzyme immobilization process are varying depending on the type of enzyme and method used. The results described herein are of considerable interest in the possible application of the immobilized enzyme.

\section{Acknowledgement}

This study was financially supported by Universiti Malaysia Pahang under Research Grant Scheme (Grant No. RDU 160322) and Universiti Malaysia Pahang Postgraduate Research Grant Scheme (Grant No. PGRS170321). The authors are grateful to Faculty of Chemical and Natural Resources Engineering, Universiti Malaysia Pahang for the research facilities.

\section{References}

[1] Jia, X., X. Ye, J. Chen, X. Lin, L. Vasseur, and M. You. 2018. Purification and Biochemical Characterization of a Cyclodextrin Glycosyltransferase from Geobacillus thermoglucosidans CHB1. Starch-Stärke. 70(1-2): 1700016.

[2] Blanco, K., F. Faria de Moraes, N. Sozza Bernardi, M. Vettori, R. Monti, and J. Contiero. 2014. Cyclodextrin Production by Bacillus lehensis Isolated from Cassava Starch: Characterisation of a Novel Enzyme. Czech J. Food Sci. 32: 48-53

[3] Ibrahim, A. S. S., Al-Salamah, A. A., El-Toni, A. M., El-Tayeb, M. A. and Elbadawi, Y. B. 2013. Immobilization of Cyclodextrin Glucanotransferase on Aminopropyl-
Functionalized Silica-coated Superparamagnetic Nanoparticles. Electron. J. Biotechnol. 16: 10-10.

[4] Voncina, B. and Vivo, V. 2013. Cyclodextrins in Textile Finishing. In M. Gunay (Ed.). Eco-Friendly Textile Dyeing and Finishing. InTech.

[5] Guzik, U., Hupert-Kocurek, K. and Wojcieszyńska, D. 2014. Immobilization as a Strategy for Improving Enzyme Properties-application to Oxidoreductases. Mol. Basel Switz. 19: 8995-9018.

[6] Mohamad, N. R., Marzuki, N. H. C., Buang, N. A., Huyop, F. and Wahab, R. A. 2015. An Overview of Technologies for Immobilization of Enzymes and Surface Analysis Techniques for Immobilized Enzymes. Biotechnol. Equip. 29: 205-220.

[7] Datta, S., Christena, L. R. and Rajaram, Y. R. S. 2013. Enzyme Immobilization: An Overview on Techniques and Support Materials. Biotech. 3: 1-9.

[8] Homaei, A. A., Sariri, R., Vianello, F. and Stevanato, R. 2013. Enzyme immobilization: An Update. J. Chem. Biol. 6: 185-205.

[9] Rakmai, J., Cheirsilp, B. and Prasertsan, P. 2015. Enhanced Thermal Stability of Cyclodextrin Glycosyltransferase in Alginate-gelatin Mixed Gel Beads and the Application for B-cyclodextrin Production. Biocatal. Agric. Biotechnol. 4: 717-726.

[10] Matijošytè, I., Arends, I. W. C. E., de Vries, S. and Sheldon, R. A. 2010. Preparation and Use of Cross-linked Enzyme Aggregates (CLEAs) of Laccases. J. Mol. Catal. B Enzym. 62: 142-148.

[11] Arya, S. K. and Srivastava, S. K. 2006. Kinetics of Immobilized Cyclodextrin Gluconotransferase Produced by Bacillus Macerans ATCC 8244. Enzyme Microb. Technol. 39: 507-510.

[12] Carneiro, L. A. B. C., T. A. Costa-Silva, C. R. F. Souza, L. Bachmann, W. P. Oliveira, and S. Said. 2014. Immobilization of Lipases Produced by the Endophytic Fungus Cercospora kikuchii on Chitosan Microparticles. Braz. Arch. Biol. Technol. 57: 578-586.

[13] Ibrahim, A. S. S., El-Tayeb, M. A. and Al-Salamah, A. A. 2010. Characterization of Immobilized Alkaline Cyclodextrin Glycosyltransferase from a Newly Isolated Bacillus agaradhaerens KSU-A11. Afr. J. Biotechnol. 9: 7550-7559.

[14] Shamel, M. M., Ramachandran, K. B., Hasan, M. and AlZuhair, S. 2007. Hydrolysis of Palm and Olive Oils by Immobilised Lipase Using Hollow Fibre Reactor. Biochem. Eng. J. 34: 228-235.

[15] Algieri, C., Donato, L., and Giorno, L. 2017. Tyrosinase Immobilized on a Hydrophobic Membrane. Biotechnol. Appl. Biochem. 64(1): 92-99

[16] Chen, G.-J., C.-H. Kuo, C.-I. Chen, C.-C. Yu, C.-J. Shieh, and Y.-C. Liu. 2012. Effect of Membranes with Various Hydrophobic/hydrophilic Properties on Lipase Immobilized Activity and Stability. J. Biosci. Bioeng. 113: 166-172.

[17] Ouyang, L. D. M. Dotzauer, S. R. Hogg, J. Macanás, J.-F. Lahitte, and M. L. Bruening. Catalytic Hollow Fiber Membranes Prepared Using Layer-by-Layer Adsorption of Polyelectrolytes and Metal Nanoparticles. Catal. Today. 156: 100-106.

[18] Man, R. C., Ismail, A. F., Ghazali, N. F., Fuzi, S. F. Z. M. and Illias, R. M. 2015. Effects of the Immobilization of Recombinant Escherichia Coli on Cyclodextrin Glucanotransferase (CGTase) Excretion and Cell Viability. Biochem. Eng. J. 98: 91-98.

[19] Fontananova, E. et al. 2015. From Hydrophobic to Hydrophilic Polyvinylidene Fluoride (PVDF) Membranes by Gaining New Insight into Material's Properties. RSC Adv. 5: 56219-56231.

[20] Man, C. R., Fauzi Ismail, A., Fatimah Zaharah Mohd Fuzi, S., Faisal Ghazali, N. and Md Illias, R. 2016. Effects of Culture Conditions of Immobilized Recombinant Escherichia Coli on Cyclodextrin Glucanotransferase (CGTase) Excretion and Cell Stability. Process Biochem. 51: 474-483. 
[21] Martín, M. T., Plou, F. J., Alcalde, M. and Ballesteros, A. 2003. Immobilization on Eupergit C of Cyclodextrin Glucosyltransferase (CGTase) and Properties of the Immobilized Biocatalyst. J. Mol. Catal. B Enzym. 21: 299308.

[22] Matte, C. R. et al. 2017. Physical-chemical Properties of the Support Immobead 150 Before and After the Immobilization Process of Lipase. J. Braz. Chem. Soc. 28: 1430-1439.

[23] Rahim, N. A., S., Sulaiman, A., Halim Ku Hamid, K., Aini Edama, N. and Samsu Baharuddin, A. 2015. Effect of Agitation Speed for Enzymatic Hydrolysis of Tapioca Slurry Using Encapsulated Enzymes in an Enzyme Bioreactor. Int. J. Chem. Eng. Appl. 6: 38-41.

[24] Elibol, M. and Özer, D. 2000. Lipase Production by Immobilised Rhizopus Arrhizus. Process Biochem. 36: 219223.

[25] Li, T., Li, S., Wang, N. and Tain, L. 2008. Immobilization and Stabilization of Pectinase by Multipoint Attachment onto an Activated Agar-gel Support. Food Chem. 109: 703-708.

[26] Jamil, N., R. C. Man, S. M. Shaarani, S. Z. Sulaiman, S. K. A. Mudalip, and Z. I. M. Arshad. 2017. Characterization of aCyclodextrin Glucanotransferase from Bacillus licheniformis. Indian J. Sci. Technol. 10.

[27] Sian, H. K. et al. 2005. Purification and Characterization of Cyclodextrin Glucanotransferase from Alkalophilic Bacillus sp. G1. Process Biochem. 40: 1101-1111.

[28] Lei, Z. and Bi, S. 2007. Preparation and Properties of Immobilized Pectinase onto the Amphiphilic PS-b-PAA Diblock Copolymers. J. Biotechnol. 128: 112-119.

[29] Mateo, C., Palomo, J. M., Fernandez-Lorente, G., Guisan, J. M. and Fernandez-Lafuente, R. 2007. Improvement of Enzyme Activity, Stability and Selectivity via Immobilization Techniques. Enzyme Microb. Technol. 40: 1451-1463.
[30] Dwevedi, A. 2016. Basics of Enzyme Immobilization. In Enzyme Immobilization. Springer, Cham. 21-44.

[31] Pang, S., Y. Wu, X. Zhang, B. Li, J. Ouyang, and M. Ding. 2016. Immobilization of Laccase via Adsorption onto Bimodal Mesoporous Zr-MOF. Process Biochem. 51: 229239.

[32] Ta, L. N. N., Nguyen, T. H. C. and Le, V. V. M. 2016. Immobilization of Saccharomyces Cerevisae Cells on Water Hyacinth Stem Pieces and Application to Repeated Batch Fermentation for Ethanol Production. Songklanakarin J. Sci. Technol. 38: 333-341.

[33] Pal, A. and Khanum, F. 2011. Covalent Immobilization of Xylanase on Glutaraldehyde Activated Alginate Beads Using Response Surface Methodology: Characterization of Immobilized Enzyme. Process Biochem. 46: 1315-1322.

[34] Sivapragasam, M., Abdullah, N., Sivapragasam, M. and Abdullah, N. 2015. Recovery of Cyclodextrin Glucanotransferase (cgtase) using Immobilized Metal Chelating Affinity Chromatography. Braz. J. Chem. Eng. 32: 43-52.

[35] Ajitha, S. and Sugunan, S. 2010. Tuning Mesoporous Molecular Sieve SBA-15 for the Immobilization of aamylase. J. Porous Mater. 17: 341-349.

[36] Brígida, A. I. S., Pinheiro, A. D. T., Ferreira, A. L. O. and Gonçalves, L. R. B. 2008. Immobilization of Candida Antarctica Lipase B by Adsorption to Green Coconut Fiber. Appl. Biochem. Biotechnol. 146: 173-187.

[37] Sun, J., Jiang, Y., Zhou, L. and Gao, J. 2010. Immobilization of Candida Antarctica Lipase B by Adsorption in Organic Medium. New Biotechnol. 27: 53-58.

[38] Wang, F., Guo, C., Liu, H.-Z. and Liu, C.-Z. 2007. Reversible Immobilization of Glucoamylase by Metal Affinity Adsorption on Magnetic Chelator Particles. J. Mol. Catal. B Enzym. 48: 1-7. 